\title{
GIS ADOPTION AND DIFFUSION AMONG SENIOR HIGH SCHOOL GEOGRAPHY TEACHERS IN TAIWAN
}

\author{
J. G. Lay ${ }^{\mathrm{a}, *}$, Y. W. Chen ${ }^{\mathrm{b}}$ \\ ${ }^{a}$ Department of Geography, National Taiwan University, No 1, Sec 4, Roosevelt Rd, Taipei City 10617, Taiwan \\ jglay@ntu.edu.tw \\ ${ }^{\mathrm{b}}$ Institute of Political Science, Academia Sinica, 128 Academia Rd, Taipei City 11529, Taiwan \\ julieyuwenchen@ntu.edu.tw
}

KEYWORDS: GIS Adoption, GIS Diffusion, Technology Acceptance Model, Social Influence Model, Taiwan

\begin{abstract}
:
The crux of this paper lies in exploring geographic information system (GIS) adoption and diffusion among high school geography teachers in Taiwan. Because the integration of GIS in the high school curriculum is relatively new, we assume that high school geography teachers require resources, training, and assistance in learning GIS and in developing modules that can be incorporated into their teaching. A number of in-service training programs have been created to this end. We aim to study what motivates geography teachers to learn GIS during in-service training. The adoption of GIS has been studied in countries such as the U.S. and Singapore; however, as there is presently no literature on Taiwan's experience, we intend to fill this gap. This is achieved through statistical analysis of primary data gleaned from a census of Taiwan's high school geography teachers. The design of the questionnaire is largely inspired by an existing measurement of two commonly cited theoretical models. The technology acceptance model (TAM) and its various modifications focus on teachers' perceived usefulness (PU) and perceived ease of use (PEOU). The social influence model (SIM), differently, postulates that teachers' usage of GIS is affected by peers and their schools. Using the census data, we provide a preliminary analysis of these two models in this paper.
\end{abstract}

\section{INTRODUCTION}

This research explores the diffusion of the geographic information system (GIS) among senior high school geography teachers in Taiwan. Taiwan's senior high school system is approximately equivalent to $10^{\text {th }}$ to $12^{\text {th }}$ grade courses in the American system. Students are divided into those who wish to major in humanities and social sciences and those who wish to major in natural sciences at the university level.

Although cartography was previously introduced to senior high school students, GIS application was not included in the senior high school geography curriculum until 1995 . When GIS first appeared as an elective course in grade 12 (or $12^{\text {th }}$ grade?), it was mostly learned by students wishing to major in humanities and social sciences after completing high school. This began to change in the 2006 and 2010 curriculums, where learning hours of cartography and GIS started to increase, and the introduction of GIS concepts moved from being a K12 $12^{\text {th }}$ grade elective course to a $10^{\text {th }}$ grade obligatory course. This transformation is largely due to promotion of GIS by a number of geography educators (e.g., professors, high school teachers) in Taiwan's in view of the deficiency of GIS knowledge among high school students. They reason that some western countries (e.g., the U.S.) have pioneered in integrating GIS into secondary education, and it is time for Taiwan to follow suit.

Working with the Ministry of Education (MOE), they adjusted the curriculum guidelines. All Taiwan's high school students are now required to learn basic GIS concepts. In grade 12, students can also take an elective course to learn about GIS applications in various areas of life. As a result, the proportion of GIS education in Taiwan's high school curriculum is rising.

In response to such a transformation and the immediate task of fully implementing the new curriculum, a number of institutions have attempted to offer complementary teaching materials to high school geography teachers. The Department of Geography at National Taiwan University (NTU), for instance, is one of the institutions entrusted by the MOE to undertake the mission of promoting GIS education. As such, it provides GIS training for teachers. Around 30 "seed" high schools have been set up to join this promotional mission. NTU started by cultivating teachers in these seed schools and is gradually expanding its coverage to more teachers in non-seed schools in Taiwan.

In addition, the MOE established a Geography Center in National Taichung Girls' Senior High School in central Taiwan to offer in-service training for teachers and to gather teaching modules for further improvement of the new curriculum.

The crux of this paper lies in exploring the in-service training of Taiwan's high school geography teachers. Because the integration of GIS in the high school curriculum is relatively new, we assume that high school geography teachers require

\footnotetext{
* Corresponding author.
} 
resources, training, and assistance in learning GIS and in developing modules that can be incorporated into their teaching. Due to the deficiency of courses geared toward cultivating GIS capabilities in most universities in Taiwan, most geography teachers do not have sufficient training in GIS concepts and skills before becoming teachers. Complementary in-service training thus becomes imperative. We aim to study what motivates geography teachers to undertake in-service training in order to pave the way for future research of how GIS as a technology becomes adopted and diffused in Taiwan.

The adoption of GIS has been studied in countries such as the U.S. and Singapore (Demirci, 2008; Yap et al., 2008). Because there is presently no literature on Taiwan's experience, we intend to fill this gap. This is achieved through statistical analysis of primary data gleaned from a nationwide census targeting 1,530 high school geography teachers in Taiwan. The design of the questionnaire is largely inspired by existing measurements of two commonly cited theoretical models (Kerski, 2003; Davis, 1989; Anderson and Jay, 2008). The technology acceptance model (TAM) and its various modifications focus on users' perceived usefulness (PU) and perceived ease of use (PEOU). The social influence model (SIM), differently, postulates that teachers' usage of GIS is affected by the opinions and attitudes of peers in the social environment in which teachers are embedded.

In the next section, we will elaborate on how the TAM and the SIM can be applied to explain the adoption and diffusion of GIS among high school geography teachers in Taiwan. Section 3 explains how we operationalize the variables proposed in the second section. Section 4 reports our preliminary findings, and Section 5 concludes this research.

\section{THEORETICAL MODELS AND HYPOTHESES}

\subsection{Technology Acceptance Model (TAM)}

The TAM has been vigorously tested and refined for explaining the adoption of various kinds of technological innovation (Davis, 1989; Lee et al., 2003; Song, Parry, and Kawakami, 2009). Theoretically speaking, we can apply the TAM to explore the adoption of GIS in Taiwan.

According to the TAM, user acceptance of new technology relies on two key elements: perceived usefulness (PU) and perceived ease of use (PEOU). Perceived usefulness refers to the extent to which a person believes that the technology can benefit his or her job performance (Davis, 1989), while perceived ease of use looks at the extent of the user's belief that the technology is "free of effort" (Davis, 1989).

Using the concept of perceived usefulness to examine GIS usage in Taiwan, we can posit that teachers are more likely to learn GIS when they perceive that its usage will enhance their job performance, such as in analyzing geographical phenomena, strengthening lectures, or even having an impact on their career advancement (Davis, 1989; Cheung, Chang, and Lai, 2000). Regarding perceived ease of use, one can posit that teachers are more likely to learn GIS when they perceive it to be easier to use. Two hypotheses can be formulated, as follows:
H1. The higher a teacher's perceived usefulness of GIS adoption, the higher the teacher's frequency of attending GIS workshops.

H2. The higher a teacher's perceived ease of GIS adoption, the higher the teacher's frequency of attending GIS workshops.

\subsection{Social Influence Model (SIM)}

Although the TAM is a commonly recognized model for studying technology acceptance and utilization, it is not without critics. A known caveat is that it mainly focuses on users' attributes, ignoring the fact that adoption and learning of a technology is often the result of social influence, such as social attitudes for or against that technology. Through rounds of conversations and exchanges of views regarding a certain technology in a certain environment, individuals decide whether to accept that technology or not. There is a collective social reinforcement involved (Rogers, 1983), and the SIM aims to address this social process (Cheung, Chang, and Lai, 2000; Malhotra and Galletta, 1999; Kelman, 1958; Fulk et al., 1987; Lee et al., 2003; Cho et al., 2007).

Applying the SIM to examine GIS adoption in Taiwan, one can argue that interpersonal connections provide geography teachers with knowledge of their peers' experiences with GIS (Anderson and Jay, 2008). Therefore, frequency of GIS training attendance could rise with support from peers. Accordingly, we can hypothesize a positive relationship between the encouragement of GIS usage by members (i.e., colleagues and friends) of a teacher's reference group and the teacher's frequency of attending GIS training (Compeau and Higgins, 1995; Anderson and Jay, 2008).

H3. The higher the encouragement of GIS usage by members of a teacher's reference group, the higher the teacher's frequency of attending GIS workshops.

The next hypothesis deriving from the SIM is in regard to support on the part of schools. Organizational support reflects the formal stance of the school towards GIS learning, which gives clues to teachers as to whether learning GIS is worthwhile or not (Compeau and Higgins, 1995). The fourth hypothesis can be formulated as follows:

H4. The higher the school support for GIS learning, the higher the teacher's frequency of attending GIS workshops.

In the study of technology diffusion, both the TAM and the SIM have been discussed and modified extensively. Most researchers recognize the utilities of both models, yet at the same time understand the partial explanatory power of both models. Conventional TAM tends to ignore structural factors, while SIM over-stresses the structural determination of human behaviors (Cho et al., 2007). Some research projects have centered on testing only one of these models, while others have attempted to test and compare both models. In the next section, we propose to statistically test and compare these two models.

\section{RESEARCH DESIGN AND METHODS}

There are approximately 1,530 senior high school geography teachers in Taiwan, and we distributed a questionnaire to all of them in 2011. The questionnaire begins with some standard 
questions to investigate the respondents' demographic characteristics (e.g., gender, educational level) and their GIS experiences. What is more important is that the questionnaire elicits information on variables deriving from the TAM and the SIM. In this section, we outline our design for testing these two models.

\subsection{Testing the TAM}

Our primary unit of analysis is individuals (i.e., teachers). The dependent variable is measured in terms of high school geography teachers' frequency of attending GIS workshops during the past five years.

Davis' (1989) six-item measurement of perceived usefulness and six-item measurement of perceived ease of use are widely used for the study of technology adoption. Our measurement of these two main variables is primarily based on Davis' design. We simplified the original 7-point scale to a 5-point scale (i.e., strongly disagree, disagree, neutral, agree, and strongly agree) (Malhotra and Galletta, 1999). Further, as Rogers (1983) rightly points out, the measurement of the adoption of each innovation should be tailored for the unique characteristics of that innovation; directly using existing measurement might not be appropriate. In our view, Davis' standard questions are indeed too abstract. Taking Rogers' view into consideration, we added 13 more specific items to measure perceived usefulness. Among them, 11 were largely modified from the indices of Kerski (2003) and Baker, Palmer, and Kerski (2009); the remaining two items measure perceived usefulness of "obtaining in-service training hours" (which is essential for teachers' career promotion in Taiwan) and "necessity in teaching." "Necessity in teaching" was created because we contend that the new geography curriculum has compelled teachers, most of whom lack GIS training before becoming teachers, to join in-service training.

\subsection{Testing the SIM}

The referral or encouragement of others within the teachers' networks - the group to whom a teacher looks to acquire clues on behavioral expectations - might affect teachers' attendance of GIS training (Compeau and Higgins, 1995). The extent to which GIS learning is encouraged by the teacher's reference group is measured by two items: invitation from colleagues in the same school and invitation from friends (i.e., noncolleagues).

Regarding the support of schools, we asked questions covering five dimensions. First, we asked the straightforward question of the degree of the school's support for teachers to undertake GIS training. Second, we asked the extent of the school's encouragement for teachers to lead students to participate in geography competitions, on the assumption that if there is a need for competition, teachers might feel the need to beef up their professional competitiveness, such as GIS skills. Third, we asked whether the school encourages teachers to compete in the design of teaching modules, which might also motivate teachers to include GIS in their modules. Fourth, we asked whether the school encourages the integration of computeraided teaching into regular education. Fifth, we asked whether the school encourages teachers to attend activities of the MOE's Geography Center, which covers GIS training.

\subsection{Preparing the Questionnaire}

The questionnaire was written in Chinese, as this is the primary language used in Taiwan. The validity of the questionnaire was first evaluated by four experts in GIS and geography education, after which a pilot test was conducted with 30 randomly selected high school geography teachers. Seventeen of them replied, yielding a response rate of $56.6 \%$. Cronbach's alpha for the aforementioned multi-item measures exceeded 0.80 , indicating that the internal construct reliability of the measures was acceptable.

The final questionnaire was mailed to high school geography teachers with a cover letter indicating the purpose and significance of this study in July 2011. As this research is ongoing, we can only present the preliminary results here. As of August 1, 2011, we received 717 returned questionnaires, yielding a response rate of $46.8 \%$. Among them, two are invalid and thus are discarded. In the end, we were able to analyze the data collected from 715 respondents.

Among the respondents, the majority of the teachers (315, $44.1 \%)$ are in the 30-39 age range. There are more female teachers $(470,65.7 \%)$ than male teachers $(245,34.3 \%)$. A large number $(398,55.7 \%)$ of Taiwan's high school geography teachers hold at least master's degrees. In addition, 299 teachers $(41.8 \%)$ hold bachelor's degrees, and $12(1.7 \%)$ even have doctoral degrees. This indicates that Taiwan's geography teachers are generally well educated.

In regard to teachers' frequency of attending GIS training, we found that the majority $(157,22 \%)$ of teachers attended twice during the past five years. The second-largest group (123, $17.2 \%$ ) attended three times during the past five years (see Figure 1). On average, teachers attended 3.21 times in the past five years. This information will be used as the dependent variable of our following test.

Figure 1. Frequency of GIS Training Attendance

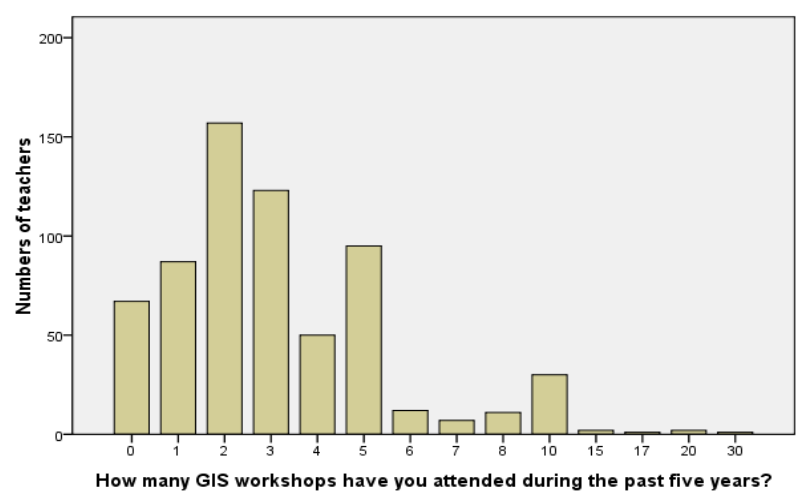

Source: GIS Census in Taiwan

In the next section, we will first use factor analysis to explore the multi-item measures to see if they really gauge the theoretical concepts that we seek to test. Afterwards, as our dependent variable is count data and it is Poisson-distributed (see Figure 1), we use Poisson regression to examine the hypotheses. 


\section{RESEARCH FINDINGS}

\subsection{Factor Analysis}

The 32 multi-item measures are subjected to a factor analysis. A varimax rotation is performed. All factors less than 0.5 are suppressed.

Three items have weak loadings $(<0.5)$ and will be excluded from further analysis. Two of those items were originally adopted from Kerski (2003) and Baker, Palmer, and Kerski (2009). They asked respondents whether GIS training could help provide analytical tools for data analysis and whether GIS training could help students memorize geography knowledge in textbooks. These two items are too weak for further analysis. The third item was designed by the authors. As stated earlier, we assumed that obtaining in-service training hours should be valid in Taiwan's case, because this is important for teachers' career promotion. However, factor analysis indicates that its loading is too weak for further analysis.

As noted, we have largely applied the measures of Davis (1989), Kerski (2003), and Baker, Palmer, and Kerski (2009) for evaluating perceived usefulness (H1). It is interesting that the 19-item measure for perceived usefulness actually loads on two factors. The first factor covers the six-item measures adopted from Davis (1989), the four-item measures are adopted from Kerski (2003) and Baker, Palmer, and Kerski (2009), and the single measure ("necessity in teaching") is of our own design. When Davis' measures load on the same factor, it suggests that the perceived utility of GIS in teaching performance matters. The inclusion of Kerski's four items in this same factor, interestingly, suggests that "enhance learning," "provide real-world relevance," "increase learning motivation and interests," and "encourage students to think geographically" can be considered as measuring the same concept. Davis' measures and our single measure focus more on the perceived utility of teaching, while Kerski's measures are more inclined to look into the learning effect of students. This implies that educators do not just think about their own teaching performance, but also consider students' learning results. Both aspects can lead educators to judge the benefits of joining GIS workshops. Table 1 provides a descriptive overview of these measures.

Table 1. Perceived Usefulness I

\begin{tabular}{|l|c|c|c|c|c|}
\hline Items & $\mathrm{N}$ & Min & Max & Mean & $\begin{array}{c}\text { Std. } \\
\text { Deviation }\end{array}$ \\
\hline $\begin{array}{l}\text { Faster accomplishment in } \\
\text { teaching }\end{array}$ & 711 & 1 & 5 & 3.61 & 0.816 \\
\hline $\begin{array}{l}\text { Improve teaching } \\
\text { performance }\end{array}$ & 709 & 1 & 5 & 3.94 & 0.646 \\
\hline $\begin{array}{l}\text { Increase teaching } \\
\text { productivity }\end{array}$ & 705 & 1 & 5 & 3.74 & 0.704 \\
\hline $\begin{array}{l}\text { Enhance effectiveness in } \\
\text { teaching }\end{array}$ & 708 & 1 & 5 & 3.72 & 0.783 \\
\hline Make it easier for teaching & 708 & 1 & 5 & 3.83 & 0.750 \\
\hline Useful in teaching & 709 & 2 & 5 & 4.08 & 0.592 \\
\hline Enhance learning & 711 & 2 & 5 & 3.95 & 0.638 \\
\hline $\begin{array}{l}\text { Provide real-world } \\
\text { relevance to subject }\end{array}$ & 709 & 1 & 5 & 4.00 & 0.700 \\
\hline $\begin{array}{l}\text { Increase learning } \\
\text { motivation and interests }\end{array}$ & 710 & 1 & 5 & 4.06 & 0.626 \\
\hline $\begin{array}{l}\text { Encourage students to think } \\
\text { geographically }\end{array}$ & 709 & 1 & 5 & 3.94 & 0.668 \\
\hline Necessity in teaching & 712 & 1 & 5 & 4.06 & 0.651 \\
\hline Cronbach's alphat 0.934 & & & & \\
\hline
\end{tabular}

Cronbach's alpha $=0.934$

Source: GIS Census in Taiwan
While four of Kerski's measuring items load on the same factor, the remaining five items load on another separate factor. Table 2 offers a descriptive overview of these measures, which we term "perceived usefulness II" in later analysis.

Table 2. Perceived Usefulness II

\begin{tabular}{|l|c|c|c|c|c|}
\hline Items & $\mathrm{N}$ & Min & Max & Mean & $\begin{array}{c}\text { Std. } \\
\text { Deviation }\end{array}$ \\
\hline $\begin{array}{l}\text { Help the integration of } \\
\text { different subjects }\end{array}$ & 708 & 1 & 5 & 3.47 & 0.756 \\
\hline $\begin{array}{l}\text { Provide opportunities for } \\
\text { teamwork in learning } \\
\text { environment }\end{array}$ & 707 & 1 & 5 & 3.54 & 0.726 \\
\hline $\begin{array}{l}\text { Help teach concepts of } \\
\text { national and municipal } \\
\text { boundaries }\end{array}$ & 707 & 1 & 5 & 3.72 & 0.799 \\
\hline $\begin{array}{l}\text { Provide students with } \\
\text { employment skills }\end{array}$ & 710 & 1 & 5 & 2.95 & 0.869 \\
\hline $\begin{array}{l}\text { Provide opportunities to } \\
\text { partner with communities }\end{array}$ & 705 & 1 & 5 & 2.98 & 0.794 \\
\hline
\end{tabular}

Source: GIS Census in Taiwan

We should note that if we change the eigenvalue from 1 to 1.5 , this factor will actually merge with the first factor, corresponding perfectly with our original assumption that there is one dimension measuring perceived usefulness.

Keeping the standard procedure of setting the eigenvalue at 1 , however, is useful for capturing the slight differences between these multi-item measures. That is, the aforementioned first factor primarily captures the utility of GIS in teaching and learning, while this second factor largely examines the "added value" of GIS adoption. It investigates whether GIS adoption will help students with their future employment and whether GIS adoption will supply opportunities for working with communities, etc.

The only exception, which we are still investigating, is why "help teach concepts of national and municipal boundaries" loads on this second factor, and not on the first factor. As we only provide a preliminary report in this paper, we cannot answer this question at this time.

Next, let us look at the items for measuring perceived ease of use (H2), peer support (H3), and school support (H4). They load onto the expected factor as initially planned, implying the validity of our measurement. Table 3 provides a descriptive analysis of the measures for perceived ease of use. As the means of these variables demonstrate, the respondents lean toward believing that when learning GIS can be easy and flexible, they are more motivated to join workshops.

Table 3. Perceived Ease of Use

\begin{tabular}{|l|c|c|c|c|c|}
\hline Items & $\mathrm{N}$ & Min & Max & Mean & $\begin{array}{c}\text { Std. } \\
\text { Deviation }\end{array}$ \\
\hline $\begin{array}{l}\text { Learning to operate GIS would } \\
\text { be easy }\end{array}$ & 710 & 1 & 5 & 3.66 & 0.811 \\
\hline $\begin{array}{l}\text { Finding it easy to get GIS to } \\
\text { do what I want GIS to do }\end{array}$ & 708 & 1 & 5 & 3.56 & 0.840 \\
\hline $\begin{array}{l}\text { Interaction with GIS would be } \\
\text { clear and understandable }\end{array}$ & 710 & 1 & 5 & 3.53 & 0.854 \\
\hline $\begin{array}{l}\text { Finding GIS to be flexible to } \\
\text { interact with }\end{array}$ & 708 & 1 & 5 & 3.50 & 0.762 \\
\hline $\begin{array}{l}\text { It would be easy to become } \\
\text { skilful at using GIS }\end{array}$ & 708 & 1 & 5 & 3.14 & 0.908 \\
\hline Finding GIS easy to use & 708 & 1 & 5 & 3.28 & 0.889 \\
\hline
\end{tabular}

Cronbach's alpha $=0.919$

Source: GIS Census in Taiwan 
Table 4 summarizes the measures for peer influence. Most respondents leaned toward being against or having a neutral position on peer influence.

Table 4. Peer Influence

\begin{tabular}{|l|c|c|c|c|c|}
\hline Items & $\mathrm{N}$ & Min & Max & Mean & $\begin{array}{c}\text { Std. } \\
\text { Deviation }\end{array}$ \\
\hline Colleagues' support & 693 & 1 & 5 & 3.01 & 0.864 \\
\hline $\begin{array}{l}\text { Friends' (i.e., non-colleagues) } \\
\text { support }\end{array}$ & 693 & 1 & 5 & 2.95 & 0.849 \\
\hline
\end{tabular}

Cronbach's alpha $=0.872$

Source: GIS Census in Taiwan

Although peer influence appears relatively less crucial, another aspect of social influence could matter. As Table 5 shows, the formal stance of schools towards GIS learning can give clues to teachers about whether learning GIS is worthwhile or not. Apart from more straightforward support for teachers' inservice training, some schools encourage teachers to participate in teaching module competitions or to lead students to join geography competitions. Having the capacity to use GIS can be important for winning these competitions and therefore prompts teachers to cultivate their GIS skills.

Table 5. School Support

\begin{tabular}{|l|c|c|c|c|c|}
\hline Items & N & Min & Max & Mean & $\begin{array}{c}\text { Std. } \\
\text { Deviation }\end{array}$ \\
\hline Support for GIS training & 708 & 1 & 5 & 3.74 & 0.788 \\
\hline $\begin{array}{l}\text { Support for teachers to lead } \\
\text { students to take part in } \\
\text { geography competitions }\end{array}$ & 707 & 1 & 5 & 3.68 & 0.769 \\
\hline $\begin{array}{l}\text { Support for teachers to } \\
\text { compete in teaching modules }\end{array}$ & 706 & 1 & 5 & 3.55 & 0.765 \\
\hline $\begin{array}{l}\text { Support for teachers to } \\
\text { integrate computer-aided } \\
\text { teaching into normal education }\end{array}$ & 707 & 1 & 5 & 3.74 & 0.766 \\
\hline $\begin{array}{l}\text { Support for teachers to attend } \\
\text { activities at the Geography } \\
\text { Center }\end{array}$ & 707 & 1 & 5 & 3.61 & 0.757 \\
\hline
\end{tabular}

Cronbach's alpha $=0.926$

Source: GIS Census in Taiwan

Lastly, Cronbach's alpha is calculated to measure the internal consistency of the items in the aforementioned five dimensions. The alpha coefficients are 0.934 (perceived usefulness I), 0.839 (perceived usefulness II), 0.919 (perceived ease of use), 0.872 (peer influence), and 0.926 (school support), confirming the consistency of these measures. This allows us to proceed to the regression analysis.

\subsection{Regression Analysis}

Although Poisson regression is suitable, in theory, for count data, there is a slight concern for overdispersion in the model (overdispersion test: 4.036). Negative binomial regression is often suggested as an alternative to tackle overdispersion. Using the LIMDEP statistical package, we were able to summarize the results of these two models for comparison (Table 6).

Table 6. Hypotheses Testing

\begin{tabular}{|l|l|l|}
\hline Variables & $\begin{array}{l}\text { Poisson } \\
\text { Regression }\end{array}$ & $\begin{array}{l}\text { Negative Binomial } \\
\text { Regression }\end{array}$ \\
\hline Perceived usefulness I & $0.154^{* *}$ & $0.154^{* *}$ \\
& $(0.025)$ & $(0.032)$ \\
\hline Perceived usefulness II & $0.155^{* *}$ & $0.16^{* *}$ \\
& $(0.024)$ & $(0.033)$ \\
\hline Perceived ease of use & $0.064^{* *}$ & $0.061^{*}$ \\
& $(0.023)$ & $(0.027)$ \\
\hline
\end{tabular}

\begin{tabular}{|l|l|l|}
\hline Peer influence & 0.019 & 0.015 \\
& $(0.023)$ & $(0.030)$ \\
\hline School support & -0.026 & -0.02 \\
& $(0.021)$ & $(0.026)$ \\
\hline Constant & $1.143^{* *}$ & $1.142^{* *}$ \\
& $(0.023)$ & $(0.032)$ \\
\hline AIC & 4.70 & 4.36 \\
\hline N & 640 & 640 \\
\hline
\end{tabular}

${ }^{\mathrm{a}}$ Numbers in parentheses are standard errors.

* Significant at $p=0.05 ;{ }^{* *}$ Significant at $p=0.01$ (two-tailed test) Source: GIS Census in Taiwan

Although there is a slight issue of overdispersion in the Poisson regression model, it is still acceptable. The results generated from both models are identical. Perceived usefulness I (H1), perceived usefulness II (H1), and perceived ease of use (H2) are statistically significant for teachers' decisions to adopt GIS. Peer influence (H3) and school support (H4) are less important. Regression analysis supports the TAM and downplays the SIM.

When teachers are deciding whether to attend GIS training or not, their self-perceived benefits of learning GIS are vital. The referral of peers or schools is less crucial. As further proof of this feature, we looked into the channels through which teachers elicit training information. We asked the respondents to indicate their frequencies of relying on various channels on a 5-point scale (never, rarely, sometimes, usually, and always). School announcements posted on bulletin boards or delivered as official documents stand out as the most popular channel. Announcements from the MOE's Geography Center are the second most popular source (Table 7).

Table 7. Channels to Acquire GIS Training Information

\begin{tabular}{|l|c|c|c|c|c|}
\hline Channels & $\mathrm{N}$ & Min & Max & Mean & $\begin{array}{c}\text { Std. } \\
\text { Deviation }\end{array}$ \\
\hline $\begin{array}{l}\text { Announcement in } \\
\text { schools }\end{array}$ & 700 & 1 & 5 & 3.60 & 1.079 \\
\hline $\begin{array}{l}\text { From colleagues in the } \\
\text { same schools }\end{array}$ & 667 & 1 & 5 & 2.54 & 1.038 \\
\hline $\begin{array}{l}\text { From friends in other } \\
\text { schools }\end{array}$ & 659 & 1 & 5 & 2.23 & 1.011 \\
\hline $\begin{array}{l}\text { GIS EDU } \\
\text { (http://gisedu.tw) }\end{array}$ & 676 & 1 & 5 & 2.55 & 1.143 \\
\hline $\begin{array}{l}\text { inservice.edu.tw } \\
\text { Geography Center }\end{array}$ & 680 & 1 & 5 & 2.75 & 1.154 \\
\hline $\begin{array}{l}\text { Social networking } \\
\text { platforms (e.g., } \\
\text { Facebook, blogs) }\end{array}$ & 640 & 1 & 5 & 1.40 & 0.745 \\
\hline Source: GIS Cens in & Taiwan & 5 & 3.06 & 1.115 \\
\hline
\end{tabular}

Source: GIS Census in Taiwan

Apart from these announcements, there are other channels through which teachers can learn about training opportunities. However, they are not as popular as the first two. For example, some teachers receive their information from colleagues and friends, and sometimes teachers consult two GIS-focused websites, GIS EDU and Inservice.edu.tw. GIS EDU is a website created by NTU's Department of Geography to help promote GIS education in Taiwan, and it is sponsored by the MOE. Inservice.edu.tw is also a project of the MOE, supplying teachers with training information.

Acquiring training information from social networking platforms (e.g., Facebook, blogs) is the least common channel. This is understandable, as social networking platforms are more for networking and other social purposes than for disseminating professional information. If teachers do seek 
information online that is relevant to their profession, GIS EDU and Inservice.edu.tw remain more important than social networking platforms.

If we interpret the regression results with the information in Table 7, we see that teachers receive information on GIS training mostly through school announcements and the MOE's Geography Center announcements. Then, it is up to the teachers to decide whether it is worthwhile to undertake GIS training or not. Peer referral is not common, nor is it crucial for teachers' final decisions to take part in training.

\section{CONCLUSIONS}

There is a top-down approach occurring to disseminate GIS in Taiwan. The MOE has spearheaded sponsoring universities and the Geography Center to organize GIS in-service training. The cooperative efforts of the government and certain higher educational bodies play leading roles. Individuals and high schools tend to be receivers of information; they are later adopters.

Through a systematic analysis of the factors that prompt teachers to take part in training, we further learned that teachers are usually enticed by the potential utilities of GIS in enhancing their teaching performance and students' learning results. Perceived ease of GIS adoption also affects their willingness to participate in training. Less important in affecting their decision to join workshops are the recommendations or preferences of their peers and their schools.

This result leads us to conclude that more effort can be put into specifying and advocating the utilities of GIS adoption through school and Geography Center announcements. It is anticipated that persuasive promotion will entice more teachers to open themselves to GIS learning and adoption. As what we present in this paper is a work in progress, we expect to complete the analysis and explore its implications for GIS promoters in the future.

\section{References from Journals:}

Anderson, J. G., and S. J. Jay. 1985. The diffusion of medical technology: social network analysis and policy research. Sociological Quarterly, 26 (1), pp. 49-64.

Baker, T. B., A. M. Palmer, and J. J. Kerski. 2009. A national survey to examine teacher professional development and implementation of desktop GIS. Journal of Geography, 108, pp. 174-185.

Cho, H., G. Gay, B. Davidson, and A. Ingraffea. 2007. Social networks, communication styles, and learning performance in a CSCL community. Computers \& Education, 49, pp. 309-329.

Compeau, D. R., and C.A. Higgins. 1995. Self-efficacy: development of a measure and initial test. MIS Quarterly, 19(2), pp. 189-211.

Cheung, W., M.K. Chang, and V. S. Lai. 2000. Prediction of internet and world wide web usage at work: a test of an extended Triandis model. Decision Support Systems, 30(1), pp. 83-100.
David, F. D. 1989. Perceived usefulness, perceived ease of use, and user acceptance of information technology. MIS Quarterly, 13(3), pp. 319-342.

Demirci, A. 2008. Evaluating the implementation and effectiveness of GIS-based application in secondary school geography lessons. American Journal of Applied Sciences, 5(3), pp. 169-178.

Fulk, J., C.W. Steinfield, J. Schmitz, and J. G. Power. 1987. A social information processing model of media use in organizations. Communication Research, 14(5), pp. 529-552.

Kerski, J. 2003. The implementation and effectiveness of geographic information systems technology and methods in secondary education. Journal of Geography, 102, pp. 128-137.

Kelman, H. C. 1958. Compliance, identification, and internalization: three processes of attitude change. Journal of Conflict Resolution, 2(1), pp. 51-60.

Lee, J. S., H. Cho, G. Gay, B. Davidson, and A. Ingraffea. 2003. Technology acceptance and social networking in distance learning. Educational Technology \& Society, 6(2), pp. 50-61.

Song, M., M.E. Parry, and T. Kawakami 2009. Incorporating network externalities into the technology acceptance model. Journal of Product Innovation Management, 26, pp.291-307.

Yap, L. Y., G. C. I. Tan, X. Zhu, and M.C. Wettasinghe. 2008. An assessment of the use of geographic information systems (GIS) in teaching geography in Singapore Schools, Journal of Geography, 107, pp. 52-60.

\section{References from Books:}

Rogers, E. M. 1983. Diffusion of innovation. New York: The Free Press.

\section{References from Other Literature:}

Malhotra, Y., and D. F. Galletta. 1999. Extending the technology acceptance model to account for social influence: theoretical bases and empirical validation. Proceedings of the $32^{\text {nd }}$ Hawaii International Conference on System Sciences 1-14.

\subsection{Acknowledgements}

We would like to thank Taiwan's National Science Council for financial support of the project “A Study of GIS Diffusion Networks of Taiwan's High School Teachers" (NSC-98-2410-H-002-153-MY3). We also wish to express our appreciation to Po-Hui $\mathrm{Yu}$ and $\mathrm{Yu}$-Lin Chi for their research assistance. 